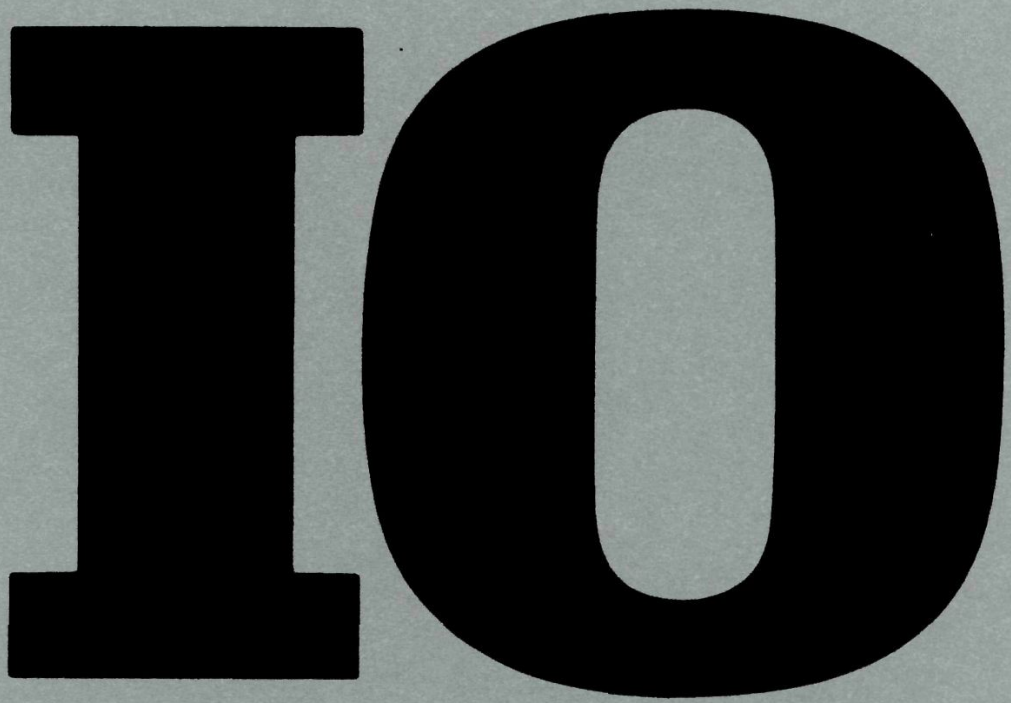

\title{
International Oyganivation
}

\author{
David M. Rowe \\ World War Economic Expansion and National Security \\ Kenneth A. Schultz \\ Do Democratic Institutions Constrain or Inform? \\ Andrew Moravesik
}

Supranational Entrepreneurs and International Cooperation

Leonard J. Schoppa

The Social Context in Coercive International Bargaining

Ronald R. Krebs

Perverse Institutionalism: NATO and the Greco-Turkish Conflict

\section{Ian Hurd}

Legitimacy and Authority in International Politics

Joseph Jupille

The European Union and International Outcomes 
Edited at the University of California, San Diego

Published quarterly by The MIT Press

Founded in 1947 by the World Peace Foundation

\author{
Robert Bates \\ Benjamin J. Cohen \\ Matthew Evangelista \\ James Fearon \\ Martha Finnemore \\ Jeff Frieden \\ Geoffrey Garrett \\ Judith Goldstein \\ Peter Gourevitch \\ Christer Jönsson \\ Miles Kahler \\ Peter Katzenstein \\ Robert $O$. Keohane \\ David A. Lake \\ Charles Lipson \\ Lisa Martin
}

Editors

Review Editors

Managing Editor

Editorial Board Chair

Editorial Board
Peter Gourevitch

David A. Lake

Stephan Haggard

Jack Snyder

Lynne L. Bush

Janice Stein

Helen V. Milner

John Odell

Louis Pauly

Robert Powell

J. David Richardson

Thomas Risse

Volker Rittberger

Ronald Rogowski

Frances Rosenbluth

Kathryn Sikkink

Beth Simmons

Anne-Marie Slaughter

Arthur Stein

Janice Stein

Beth V. Yarbrough

Mark W. Zacher

INTERNATIONAL ORGANIZATION invites the submission of original manuscripts on all aspects of world politics and international political economy. Authors should follow the guidelines published annually in the Winter issue. Guidelines also may be found on the World Wide Web at http://mitpress.mit.edu/IO.

Address for submissions:

Lynne Bush

Managing Editor

International Organization

IR/PS

University of California, San Diego

9500 Gilman Drive

La Jolla, CA 92093-0519

Statements and opinions expressed in International Organization are the responsibility of the authors alone and do not imply the endorsement of the Board of Editors, the Board of Trustees of the World Peace Foundation, the University of California, or The MIT Press.

For abstracting listing and price information, please refer to the back of this issue.

Periodicals postage is paid at Boston, Mass., and at additional mailing offices.

(1) 1999 by The IO Foundation and the Massachusetts Institute of Technology ISSN (0)20-8183

$\otimes$ This publication is printed on acid-free paper. 


\section{International Organization Volume 53, Number 2, Spring 1999}

\section{Articles}

World Economic Expansion and National Security in Pre-World

War I Europe David M. Rowe

Do Democratic Institutions Constrain or Inform? Contrasting Two Institutional Perspectives on Democracy and War Kenneth A. Schultz

A New Statecraft? Supranational Entrepreneurs and International Cooperation Andrew Moravcsik

The Social Context in Coercive International Bargaining

Leonard J. Schoppa

Perverse Institutionalism: NATO and the Greco-Turkish Conflict

Ronald R. Krebs

Legitimacy and Authority in International Politics Ian Hurd

\section{Research Note}

The European Union and International Outcomes Joseph Jupille 


\section{Contributors}

Ian Hurd is a Ph.D. candidate in the Department of Political Science at Yale University, New Haven, Connecticut. He can be reached at ian.hurd@yale.edu.

Joseph Jupille is a Ph.D. candidate in the Department of Political Science, University of Washington, Seattle, Washington. He can be reached at jjupille@u.washington.edu.

Ronald R. Krebs is a Ph.D. candidate in the Department of Political Science, Columbia University, New York, New York. He can be reached at rrk9@columbia.edu.

Andrew Moravcsik is Associate Professor of Government, Harvard University, Cambridge, Massachusetts. He can be reached at moravcs@fas.harvard.edu.

David M. Rowe is Assistant Professor of Political Science at Ohio State University. He can be reached at rowe.47@osu.edu.

Leonard J. Schoppa is Associate Professor in the Department of Government and Foreign Affairs at the University of Virginia, Charlottesville, Virginia. He can be reached at ljsk2@virginia.edu.

Kenneth Schultz is Assistant Professor of Politics and International Affairs at Princeton University, Princeton, New Jersey. He can be reached at kschultz@wws.princeton.edu. 
International Organization gratefully acknowledges the assistance of the following additional reviewers in 1998:

\begin{tabular}{l} 
Emanuel Adler \\
Vinod Aggarwal \\
Hayward R. Alker \\
James E. Alt \\
Karen Alter \\
Lisa Anderson \\
Jonathan Aronson \\
Deborah Avant \\
David Baldwin \\
Matt Baum \\
Nathaniel Beck \\
Mark Beissinger \\
Coit Blacker \\
Bruce Bueno de Mesquita \\
William Chandler \\
Thomas Christensen \\
Peter Cowhey \\
Russell Dalton \\
I. M. Destler \\
Richard F. Doner \\
Jack Donnelly \\
John Duffield \\
Martha Finnemore \\
Benjamin Fordham \\
Jeff Frieden \\
Scott Gartner \\
Kurt Gaubatz \\
Gregory Gause \\
Michael J. Gilligan \\
Judith Goldstein \\
Peter M. Haas \\
Peter A. Hall \\
Dan Hallin \\
Kathleen Hancock \\
David Hendrickson \\
Allen Hicken \\
\hline Jation
\end{tabular}

Michael Hiscox

Raymond F. Hopkins

Thomas Ilgen

Torben Iversen

Harold K. Jacobson

Robert Jervis

David Kang

Ethan B. Kapstein

Robert Keohane

Yuen Foong Khong

Stephen Kobrin

Edward A. Kolodziej

Friedrich Kratochwil

Lawrence Krause

Charles Kupchan

Deborah Larson

Fred Lawson

Jeffrey Legro

Jack S. Levy

Marc Levy

Karen Litfin

Ian Lustick

Edward Mansfield

David Mares

Michael Mastanduno

Andrew McIntyre

Timothy McKeown

Ronald Mitchell

Jeannette Money

Andrew Moravcsik

Patrick M. Morgan

James Morrow

Barry Naughton

Emerson Niou

John R. Oneal
Antonio Ortiz

Robert Paarlberg

T. J. Pempel

Samuel Popkin

John Ravenhill

Edward Ray

James Lee Ray

Simon Reich

Edward Rhodes

Mark Rosenblum

Bruce Russett

Richard J. Samuels

Wayne Sandholtz

Cheryl Schonhardt-Bailey

Leonard Schoppa

Herman Schwartz

Martin Shapiro

Randolph M. Siverson

Alastair Smith

Duncan Snidal

Jack Snyder

Etel Solingen

Steven Spiegel

Hendrik Spruyt

Michael Thies

William R. Thompson

George Tsebelis

Stephen Van Evera

Steven K. Vogel

Harrison Wagner

Celeste Wallander

Stephen Walt

Steven Weber

Alexander Wendt

Oran Young 


\section{Abstracts}

\section{World Economic Expansion and National Security in Pre-World War I Europe}

by David M. Rowe

I build on the Stolper-Samuelson theorem from international trade theory to argue that profound and rapid changes in the costs and risks of international economic exchange can significantly influence the security politics of states. Increasing exposure to the international economy will increase the state's difficulty of mobilizing locally abundant resources for security purposes and ease the difficulty of mobilizing locally scarce resources. Declining exposure reverses these effects. A preliminary survey of the five European great powers before World War I supports the pattern of shifting economic constraints predicted by the theory and further suggests that international economic expansion was an important cause of World War I. The theory thus challenges the conventional wisdom that trade promotes peace. It also has important implications for several other areas of international relations, including the relationship between trade and military power, the relative gains debate, and the dynamics of hegemonic theory.

\section{Do Democratic Institutions Constrain or Inform? Contrasting Two Institutional Perspectives on Democracy and War by Kenneth A. Schultz}

I contrast two perspectives on how democratic institutions affect international crisis behavior and offer an empirical test designed to discriminate between them. The institutional constraints argument suggests that democratic leaders face greater political risks in waging war because voters can easily sanction them for failed or costly policies. The informational perspective suggests that democratic institutions help reveal information about a government's preferences either by increasing the transparency of decision making or by enhancing the credibility of its signals. A formal model of crisis bargaining shows that the two perspectives make opposite predictions about how target states respond when challenged by a democratic state. Competing hypotheses are tested using a data set of militarized disputes, and the results are consistent with the predictions of the informational perspective. In particular, challenges made by democratic states are less likely to be resisted militarily than those made by nondemocratic states. 


\title{
A New Statecraft? Supranational Entrepreneurs and International Cooperation
}

\author{
by Andrew Moravesik
}

Studies of international regimes, law, and negotiation, as well as regional integration, near universally conclude that informal political leadership by high officials of international organizations- "supranational entrepreneurship"-decisively influences the outcomes of multilateral negotiations. Scholarship on the European Community (EC), in particular, has long emphasized informal agenda setting, mediation, and mobilization by such officials. Yet the research underlying this interdisciplinary consensus tends to be anecdotal, atheoretical, and uncontrolled. The study reported here derives and tests explicit hypotheses from general theories of political entrepreneurship and tests them across multiple cases-the five most important EC negotiations-selected to isolate informal entrepreneurship and control for the parallel actions of national governments. Two findings emerge: First, supranational entrepreneurship in treatyamending EC decisions is generally redundant or futile, occasionally even counterproductive. Governments can and do almost always efficiently act as their own entrepreneurs. Second, rare cases of entrepreneurial success arise not when officials intervene to help overcome interstate collective action problems, as current theories presume, but when they help overcome domestic (or transnational) collective action problems. This suggests fundamental refinements in core assumptions about the level and source of transaction costs underlying general theories of international regimes, law, and negotiation.

\section{The Social Context in Coercive International Bargaining}

by Leonard J. Schoppa

Even as social constructivist approaches make inroads into the field of security studies, the study of coercive international bargaining continues to be dominated by materialist models. Bargaining theorists ranging from Thomas Schelling to James Fearon tell us that coercion works primarily through rational material means: nations give in when they face credible threats from more powerful nations. In this article I borrow from work in the field of social psychology that identifies several ways in which coercive bargaining outcomes tend to vary, depending on the social context in which they take place: pressure tends to produce more concessions when exercised within a social hierarchy, when a threat is regarded as legitimate under operative social norms, and when the parties trust one another. Arguing that we ought to see similar patterns in international coercive bargaining, I then test the plausibility of these hypotheses by examining recent trends in U.S.-Japan economic bargaining. The empirical case is also used to examine the relatively neglected question of what drives the process of change in norms and other aspects of the social context.

\section{Perverse Institutionalism: NATO and the Greco-Turkish Conflict by Ronald R. Krebs}

Neoliberal institutionalists believe that alliances, within their boundaries, create "zones of stability" and cooperation. Structural realists, on the other hand, deny that alliances can independently shape the behavior of their members. In contrast, I unite the liberal belief that institutions matter with the classical realist skepticism as to their effects and argue that under certain conditions alliances can intensify conflict between their members. I develop a number of "realist institutionalist" propositions, borne out in the Greco-Turkish case, regarding the effects of membership in a multilateral alliance on small powers. The fate of these Aegean neighbors within the Atlantic alliance serves as a cautionary tale for NATO expansion, balancing the success story of Franco-German reconciliation. If Greece and Turkey's past be- 
comes East-Central Europe's future, enlargement will prove far most costly than anyone presently anticipates.

\section{Legitimacy and Authority in International Politics by Ian Hurd}

The idea that the legitimacy of international institutions affects state behavior is increasingly common in discussions of international relations, and yet little has been said about what the term legitimacy means or how it works. This is peculiar, since legitimacy is widely cited in domestic social studies as a major reason, along with coercion and self-interest, that actors obey rules. I examine the concept of legitimacy, defined as the internalization of an external rule, as it is used in domestic studies and in international relations, and find that the existence of institutions that states accept as legitimate has important implications for theories of international relations. Using the norms of sovereign nonintervention as an illustration, I compare coercion, self-interest, and legitimacy as three motivations for rule-following by states. Selfinterest and coercion, alone or together, are insufficient to sustain the pattern of behavior we recognize as the system of sovereign states. The degree of settledness of borders, especially among states of unequal power, indicates that the institution of sovereignty owes part of its persistence to the widespread acceptance by states of the norms of sovereignty as legitimate. This is important for international relations because the existence of legitimate rules signals the presence of authority, which is inconsistent with the received image of the international system as anarchic. I conclude the article by charting a course of further research into the ideas of legitimacy, authority, and anarchy.

\section{The European Union and International Outcomes} by Joseph Jupille

Analysts of the European Union (EU) and international bargaining have generally failed to appreciate how the shift within the EU from unanimity to qualified majority voting has affected European bargaining positions and international outcomes. I analyze the international effects of changes in EU decision-making rules with a simple spatial model and assess the utility of the model in two cases that span the entry into force of the Maastricht Treaty. The EU can decisively shape international outcomes by concentrating the weight of its fifteen member states on a single substantive position and rendering that position critical to any internationally negotiated agreement. The findings generalize to numerous areas of EU external relations and suggest that analysts should attend specifically to the EU and more generally to domestic and regional institutional factors in explaining international bargaining outcomes. 